\title{
Arable Crop Farmers Preference for Agricultural Information Sources and Adoption of Technology in Edo State, Nigeria
}

\author{
Dr. Harrison Oriakhi, Dr.D.U.Okoedo-Okojie \\ School of science and technology, national open university of Nigeria, Benin study centre \\ Department of agricultural economics, and extension services, university of Benin, Benin City, Nigeria.
}

\begin{abstract}
This study examined the accessibility of arable crop farmers to agricultural information in Edo State. A total of 180 farmers from six randomly selected communities were used for the study. Data were collected with interview schedule, only 142 interview schedule were however found useful for analysis. Data were analysed using both descriptive and inferential statistics. The study result revealed that crop farmers preferred radio as the most use channel of agricultural information (mean=2.33). Improved seedlings and varieties was the most adopted technology. Increased yields (mean=2.34), increased income (mean=2.20) and proper use of improved varieties (mean=2.18) were found to be the major benefits derived from the use of agricultural information. Hypotheses testing of relationship showed that respondents sex (mean $=0.488$ ), marital status (mean $=0.352)$ had no significant relationship with crop farmers sources of agricultural information. The study recommends the integration and mobilization of the various informal groups in the rural area in the information dissemination network of agricultural programmers, the employment and use of town carriers in the rural areas to create awareness as regards new developed agricultural technologies, the establishment of information centers at the local government headquarters.
\end{abstract}

\section{Introduction}

The neglect of the agricultural sector in favour of the oil sector in the early 1970's in combination with the nature of the agricultural system, which was characterized by rudimentary technologies, had severe impact on the living conditions of the farmers and the population (Erie, 1996). Nigeria is endowed with great potentials for a highly productive and profitable agricultural sector. According to Central Bank of Nigeria (CBN 2002), this enormous resource base, if well managed could support a vibrant agricultural sector capable of ensuring self sufficiency in food and raw materials for the industrial sector as well as providing gainful employment for the teeming population. About $70 \%$ of the Nigerian population resides in rural areas depending largely on agriculture for sustenance (Gana, 2001).

However, agriculture with its positive impact on the Nigerian populace is faced with myriad of problems among which is low utilization of technologies. The low utilization of technologies by the farmers may be ascribed to inadequacy of information. Aina (1989) stated that lack of information on modern agricultural technology is a key factor limiting agricultural development in Nigeria. Low accessibility to agricultural information leads to low adoption of improved technologies, which invariably affects farmers' productivity and could lead to poverty ( Ozowa,2005). Adoption of improved farm practices requires adequate information, which has to be effectively disseminated so that the clientele receives it, understands it and regards it as a valid basis for action. Information, in a broad context refers to organized data recorded in various forms (Yahaya, 2003). It is a raw resource for knowledge. Information could also be messages that are perceivable and recognizable value to the receiver. In the agricultural sector, farmers need information about their agricultural activities. For instance, while it has been established that farmers use various media sources (Keregero, 1993), it is where farmers seek information that they also find information relating to agricultural practices ranging from agronomic, processing and storage, which are of tremendous importance to the success of most farming business. According to Yahaya (2003), the choice usually lies with the source of the message to be transmitted, the source of the agricultural message must be knowledgeable about a particular channel of communication before employing it. The undisputable fact is that different channels perform different functions in the transmission of information on farm matters (agricultural development), depending on the stage of adoption process, the characteristics of innovation, the socio - economic and personal characteristics of audience (Farinde, 1991; Njoku, 1990). Farinde (1991) and Farinde and Jibowo (1994), have established that the effectiveness of any communication channel depends most in particular on its selection as an appropriate channel or medium of communication. The selection depends on the size and type of audience, the characteristics of methods, e.g cost of procurement, complexity, availability and feedback potential (Farinde, 1991). Any system initiating and stimulating development has a responsibility to provide and disseminate information about its activities to make the people knowledgeable about things happening around them, and also generate in them the right attitudes and encourage the adoption of desirable value systems. The purpose of this 
study was to assess crop farmers useage of different source for agricultural information and adoption of technology in southern agricultural zone of Edo State, Nigeria

\section{Objectives Of The Study.}

The general objective of the study was to assess crop farmers useage of different source for agricultural information in southern agricultural zone of Edo State, Nigeria. Specific objectives were to:

1. ascertain the crop farmers preferred media source for agricultural information in the area;

2. examine respondents awareness of agricultural technologies in the study area;

3. identify adoption level of crop farmers due to acquired agricultural information;

4. identify the benefits derived from the use of agricultural information.

\section{Hypothesis Formulated}

A null hypothesis formulated for the study is there is no significant relationship between respondents sex and marital status and source of agricultural information

\section{Methodology}

A multi-stage sampling technique was adopted. The first stage was the purposive selection of southern agricultural zone of Edo State, Nigeria because of crop farming. The vegetation of this area is thick mangrove with average rainfall of $252-254 \mathrm{~cm}$ and average temperature ranging from a minimum of 24 centimetres to a maximum of 33 centimetres (FOS, 2008). The inhabitants of this area are mostly farmers cultivating arable and cash crops. Some of the crop cultivated are cassava, yam, maize, plantain, cocoa, oil palm, orange trees etc. the second stage was to purposively select two local government areas (LGAs) i.e Orhionmwon and Uhunmwonde were arable crop farming is predominant in the zone. The third stage was the random selection of three communities from each LGA. The communities selected were Ugoneki, Urhokhuosa, Ugomoso (Uhunmwonde), Owa, Ogan and Ugo-Neyekorhionmwon ( Orhionmwon). In the fourth stage, 30 farmers were randomly selected in each commnunities from the list of registered farmers in the various communities obtained from the Edo State Agricultural Development Programme, thus making a total of 180 respondents selected for the study. An interview schedule was constructed to elicit response from the farmers. Data were analyzed using descriptive and inferential statistical tool of frequency count, percentage, mean and chi-square analysis was used for testing hypothesis. Respondents' preference for agricultural information source(s) was measured in a 3 point rating scale of highly preferred coded 3 , preferred coded 2 and not preferred coded 1 . A mean score of 2.0 $(3+2+1=6 / 3=2)$ and above was taken that a particular source was preferred by respondents.

\section{Respondents Preference For Agricultural Information}

\section{Results And Discussions}

The results in Table 1 showed that radio channel (Mean=2.33) was respondents most preferred information source. This result agrees with that of Ajayi (2003) that the use of the radio was the most popular among farmers in South West of Nigeria. The popular use of radio by the farmers is probably due to the fact that many farmers can afford to purchase a transistor radio as it is cheap, more accessible and easy to maintain than other mass media. Ngechu (1991), Olowu and Igodan (1989) and George (1991) also confirmed this in their various studies. The use of fellow farmers as source of information was ranked second (Mean= 2.32). The access of fellow farmers with numerous sources of information is useful in bringing various information back to their communities. Antholt (1994) however stated that the rise in farmers preferring fellow farmers as a firsthand source of information may be due to the apparent ineffectiveness in the public extension services in developing countries. The use of extension agents ranked third as the major source of information $(M e a n=2.32)$. This result agrees with the view of Zwane (1992) that the role of the extension agent is to educate, propagate and extend recent proven agricultural innovation to farmers. Erie (1996) however stated that the extension agents have not been effective as information dissemination channel because of the farmer/extension agent ratio. He puts the ratio at about 1:3,000 as against the 1:400 found to have achieved a medium of success in some Asian countries. The least preferred information sources are the newspaper and agricultural bulletin/posters which apparently was likely to be due to the respondents level of literacy, as only literate audience can read and understand the message contents. Moemeka (1990) had earlier given a reason for farmers rejection of the print media in that only literate member of the society can understand the massage contents, non literate members will have to depend on an interpreter before they can benefit, and most of the print media are located in the urban centres and finally, the cover price are not within the reach of the ordinary farmers. 
Table 1: Ranking of Information Sources Preferred by Respondents'

\begin{tabular}{|l|l|l|}
\hline Information sources & Mean & Standard deviation \\
\hline Radio & $2.33^{*}$ & 0.73 \\
\hline Fellow farmers & $2.32^{*}$ & 0.73 \\
\hline Extension agents & $2.32^{*}$ & 0.80 \\
\hline Television & $2.18^{*}$ & 0.75 \\
\hline Commercial agents & 1.86 & 0.80 \\
\hline Agric. Bulletin/posters & 1.74 & 0.81 \\
\hline Newspaper & 1.67 & 0.78 \\
\hline
\end{tabular}

Source: Field Survey, 2012. Preferred* ( Mean $\geq 2.00$ )

\section{Respondents' Awareness Of Agricultural Technologies}

The results in Table 2 showed respondents awareness of the existence of agricultural technologies in the study area. Most (75.4\%) of the respondents were aware of improved varieties/ seedlings. The highest awareness of improved varieties/seedlings is an indication that farmers in the study area had more accessibility to new technological messages relating to improved seedlings/varieties of crops than any other proven technology. This was followed by processing (75.3\%) and fertilizer application (73.9) in that order. Pesticides/herbicides application had the least awareness (61.3\%). This result showed that a high percentage of the respondents were aware of the new agricultural technologies.

Table 2: Respondents' Awareness of Agricultural Technologies

\begin{tabular}{|l|l|l|l|l|}
\hline Agricultural technologies & Yes & & No & \\
\hline & Freq & \% & Freq & \% \\
\cline { 2 - 5 } Improved seedlings/varieties & 107 & 75.4 & 35 & 24.6 \\
Processing & 106 & 75.3 & 34 & 24.7 \\
Fertilizer application (NPK) & 105 & 73.9 & 27 & 26.1 \\
Spacing & 102 & 71.8 & 40 & 28.2 \\
Storage & 102 & 71.8 & 40 & 28.2 \\
Pest and disease control & 94 & 66.2 & 48 & 33.8 \\
Pesticides/herbicides application & 87 & 61.3 & 55 & 38.7 \\
\hline
\end{tabular}

Source: Field Survey, 2010.

VII. Adoption Level Of Respondents' Due To Agricultural Information Received

Table 3 shows the adoption level of agricultural technologies due to agricultural information received by the respondents. Improved varieties/seedlings had the highest adoption (55.0\%). However, about $23.9 \%$ of the respondents adopted and discontinued while $21.1 \%$ did not adopt the technology. Storage ranked second with $53.5 \%$ adopted, $21.1 \%$ adopted and discontinued while $25.4 \%$ did not adopt the technology. Conversely, herbicides/pesticides application was the least adopted technology with $(32.4 \%)$ while $21.1 \%$ adopted and discontinued and $46.5 \%$ did not adopt the technology. This is an indication that their adoption level of improved technology is affected by farmers awareness of technological information pertaining to the crop. This result is in agreement with the view of Ekong (2003) that awareness is the first stage in the adoption process. It involves the individual learning of the existence of an innovation. However at this stage, the farmer has little knowledge about it. He may have heard about the innovation from other family members, friends, neighbours, the mass media, change agents, sales promoters or local co-operative organizations. Depending upon the individuals felt need, he might want to go on and find out more about the innovation. Obinne and Anyanwu (1991) also stated farmers adoption of innovation is influenced by variables pertaining not only to himself but also those related to the innovations and method of information dissemination which influences his response. Barao (1992) also reported that achieving an acceptable level of available technology adoption at the farm level is a function of economics and characteristics of the technology such as simplicity, visibility of results, usefulness towards meeting an existing needs and low capital investment. Hence, improved seedlings and varieties were mostly adopted because of their simplicity. 
Table 3: Adoption Level of Respondents

\begin{tabular}{|c|c|c|c|c|c|c|}
\hline \multirow[t]{2}{*}{ Agricultural Technologies } & \multicolumn{2}{|c|}{ Adopted } & \multicolumn{2}{|c|}{$\begin{array}{l}\text { Adopted } \\
\text { and } \\
\text { discontinue } \\
\text { d }\end{array}$} & \multicolumn{2}{|c|}{$\begin{array}{l}\text { Not } \\
\text { adopted at } \\
\text { all }\end{array}$} \\
\hline & Freq & $\%$ & Freq & $\%$ & $\begin{array}{l}\text { Fre } \\
\text { q }\end{array}$ & $\%$ \\
\hline Improved varieties/seedlings & 78 & 55.0 & 34 & 23.9 & 30 & 21.1 \\
\hline Storage & 76 & 53.5 & 30 & 21.1 & 36 & 25.4 \\
\hline Spacing & 70 & 49.3 & 31 & 21.8 & 41 & 28.9 \\
\hline Processing & 67 & 47.2 & 34 & 23.9 & 41 & 28.9 \\
\hline Fertilizer application & 60 & 42.3 & 35 & 24.6 & 47 & 33.1 \\
\hline Pest and control & 57 & 40.1 & 27 & 19.0 & 58 & 40.9 \\
\hline Herbicides/pesticides application & 46 & 32.4 & 30 & 21.1 & 66 & 46.5 \\
\hline
\end{tabular}

Source: Field Survey, 2012.

\section{Respondents' Benefits From The Use Of Agricultural Information}

The results in Table 4 showed respondents perceived increased yield at harvest (Mean=2.34) was the most benefit to crop farmers in the study as a result of agricultural information. This was followed by increased income from their proceeds (Mean=2.20). Logically, high rating of increased income might have been as a result of increased yield at harvest as this will bring more money to the farmers. The Table result also showed that respondents' access to credit (Mean=1.63) was not beneficial to crop farmers, despite the increase in yield and income. This could be attributed to some conditions associated with getting credit facility from formal and non formal financial institutions.

Table 4: Respondents' benefits from the use of Agricultural Information

\begin{tabular}{|c|c|c|}
\hline Benefit variable & Mean & Standard deviation \\
\hline Increased yield at harvest & $2.34 *$ & 0.74 \\
\hline Increased in income & $2.20 *$ & 0.79 \\
\hline $\begin{array}{l}\text { Proper use of improved seedlings and } \\
\text { agricultural practices }\end{array}$ & $2.18^{*}$ & 0.84 \\
\hline Improved storage and processing & $2.15^{*}$ & 0.73 \\
\hline Improvement in standard of living & $2.13 *$ & 0.72 \\
\hline $\begin{array}{l}\text { Enhancement of social status in the } \\
\text { community }\end{array}$ & $2.10^{*}$ & 0.70 \\
\hline Effective disease and pest control & 1.82 & 0.88 \\
\hline Proper use of herbicides and pesticides & 1.73 & 0.81 \\
\hline Access to credit & 1.63 & 0.79 \\
\hline
\end{tabular}

Beneficial: Mean $\geq 2.00$

\section{Relationship between respondents' characteristics}

\section{(sex and marital status) and sources of agricultural information}

The results in Table 5 revealed that, both sex and marital status of respondents did not have any significant relationship with their access to agricultural information. This may implies that both variables play no significant role in crop farmers accessibility to agricultural information in the study area.

Table 5: Respondents' between respondents' Sex and Marital Status and sources of agricultural information

\begin{tabular}{|l|l|l|}
\hline \multicolumn{1}{|c|}{ Independent variables } & $\chi^{2}$ cal & Decision \\
\hline Sex & 0.488 & Not significant \\
Marital status & 0.352 & Not significant \\
\hline
\end{tabular}

$\mathrm{X} 2$ tabulated $=1.96$. Significant at 0.05 level. 


\section{Conclusion And Recommendations}

The study has reveals that rural population yearn for relevant information to improve their existing circumstance, the importance of acquisition of agricultural information to farmers and the quest for the nation to attain self sufficiency in agricultural development. Low acquisition of agricultural information leads to low adoption of improved technologies, which invariably affects farmers' productivity and could lead to poverty. The information should be relevant to farmers' needs and must be understandable and timely. For any nation to embrace development in the agricultural sector, it has to fully appreciate and recognize the concept and importance of an effective and efficient agricultural information system. The study therefore recommends

1. The integration and mobilisation of the various informal groups in the rural area in the information dissemination network of agricultural programmes.

2. The employment and use of town carriers in the rural areas to create awareness as regards new developed agricultural technologies.

3. The establishment of information centres at the local government headquarters.

\section{Reference}

[1]. Aina, L. O (1989): Education and training of librarians for agricultural information work in Africa. Quarterly Bulletin of IAALD. Vol. 34, No. 1-2 pp. 64-70.

[2]. Ajayi, M. T. (2003): "Analysis of Mass Media Use for Agricultural Information by Farmers in Nigeria", Journal of Extension Systems, Vol. 19, No 2, pp $45-55$

[3]. Antholt, C. H. (1994): "Getting Ready for the Twenty - First Century: Technical Change and Institutional Modernization in Agriculture". World Bank Technical paper 217. Washington, D.C.

[4]. Barao, S. M. (1992): Behavioural Aspects of Technology Adoption. Journal of Extension 30 (2).

[5]. Central Bank of Nigeria (2002): "The Changing Structure of Nigerian Economy and implications for Development", CBN Publications, pp 31-40

[6]. Crosson, P and Anderson J.R (1992): "Resources and Global Food Prospects:- Supply and Demand for Cereals in 2030. World Bank Technical paper 184, Washington D.C

[7]. $\quad$ Ekong, E.E. (2003): An Introduction to Rural Sociology ( $2^{\text {nd }}$ ed), Dove Educational Publishers, Ugo, Nigeria p. 271.

[8]. Erie, A. P (1996): "Communication in Extension": In Issues in Modern Agriculture edited by E. U. Tibi and Erie, A. P. Pon Publishers Limited, Agbor, Delta State, pp $54-63$.

[9]. Farinde A.J and Jibowo, A. A (1994): ' Effectiveness of Extension Teaching Methods for Disseminating Improved Agricultural Technologies in Lagos State” Nigeria Journal of Agriculture Science and Technology, Vol. 4, No 1, pp 20-32.

[10]. Farinde, A.J (1991): 'Effectiveness of the Extension Teaching Methods Used in Disseminating Improved Agricultural Technologies in Lagos State'. Unpublished M. Phil Thesis, Obafemi Awolowo University, Ile-Ife, pp232

[11]. Federal Office of Statistics (2008): 'Poverty and Agricultural Sector in Nigeria' Federal Office of Statistics (FOS), Abuja, Nigeria, p 1-33.

[12]. Gana, A.S. (2001): ' Let praise the courage of the peasant farmer' In: SPORE No 94, Centre for Agriculture and Rural Cooperation (CTA), Wageningen, The Netherlands.

[13]. George, N. (1991): "The Dilemna of Appropriate Media Selection for Dissemination of Development Information": In S.T. Kwame Boafo and Nancy George (eds). Communication Processes Alternative Channels and Strategies for Development Support, Ottawa: (IDRC

[14]. Keregero, K. J. B. (1995): " Gender Access and Equity in Adult Education in Swaziland”, Journal of AALAE. 9(1), 12-24.

[15]. Moemeka, A. A (1990): “ Mass media communication and rural dwellers. towards effectiveness of developing messages”, In: Oso, L and Adebayo, L. (ed) Communication and Rural Development in Nigeria. Ogun State Printing Corporation, Abeokuta, 1-12.

[16]. Ngechu, M. (1991): "Feasibility Study Radio Dissemination of Agricultural Research to Small - Scale Men and Women Farmers in Kenya" Unpublished Report Prepared for the International Development Research Center, Ottawa, Canada.

[17]. Njoku, J.E. (1990): "Factors Influencing the Adoption of Improved at-palm production technologies by small holders in Imo State". Nigeria. Paper presented at the $3^{\text {rd }}$ National Farming System Research Network Workshop at University of Calabar. $14^{\text {th }}$ August, 1990.

[18]. Okwu, O.J. and Obinne, C.P. (2000): "Organizational communication and job satisfaction: an empirical study of village extension agents in Ogun State Agricultural Development Programme Manpower Journal, Vol. XXXV, No. 4 Jan-March, 2000

[19]. Olowu, T. A. and Igodan, C.O (1989): "Farmers Media use pattern in Six Villages of Kwara State". Nigerian Journal of Rural Extension and Development, 3 (2), pp $98-102$

[20]. Ozowa, V.N. (2004): "Information Needs Small Scale Farmers In Africa: In Nigeria Example". Quarterly Bulletin of the International Association of Agricultural Information Specialist, IAALD/CABI, Vol. 40. No 1, hppt: www. yahoo search, September, 2004 reprinted.

[21]. Yahaya, K.M. (2003): Development Communication: Lesson From Change and Social Engineering Projects, Corporate Graphics Limited, Ibadan, Oyo State, $1^{\text {st }}$ ed. Pp.

[22]. Zwane, E. M. (1992): "Agricultural Extension in Gazankulu” In Hinzen H; (ed): Adult Education and Development, Germany, 